ERC Working Papers in Economics 17/04

May / 2017

\title{
Trade and Commodity Taxes as Environmental Instruments in an Open Economy
}

\author{
Onur A. Koska \\ Department of Economics, Middle East Technical University, Ankara, Turkey \\ E-mail: koska@metu.edu.tr \\ Phone: + (90) 3122103046 \\ Frank Stähler \\ Department of Economics, University of Tübingen, Tübingen, Germany and \\ Department of Economics, University of Adelaide, Adelaide, Australia and \\ Center for Economic Studies, The Ifo Institute (CESifo), Munich, Germany \\ E-mail: frank.staehler@uni-tuebingen.de
}

\section{Onur Yeni}

Department of Economics, Hacettepe University, Ankara, Turkey

E-mail: oyeni@hacettepe.edu.tr 


\title{
Trade and Commodity Taxes as Environmental Instruments in an Open Economy
}

\author{
Onur A. Koska* Frank Stähler ${ }^{\dagger}$ Onur Yeni ${ }^{\ddagger}$ \\ Version of May 9, 2017
}

\begin{abstract}
In a simple reciprocal dumping model of trade, this study scrutinizes the strategic role of trade and commodity taxes as environmental instruments when consumption of an imported product generates pollution. The results suggest that both trade and commodity taxes have important implications on countries' integration through trade. For sufficiently small values of the marginal disutility from pollution, the country claiming responsibility for pollution prefers commodity taxes over import tariffs, and compared to the case of trade policies, free trade can be maintained for larger values of the marginal disutility from pollution when commodity taxes are used strategically as environmental instruments.
\end{abstract}

JEL-Classification: F12; F18

Keywords: International trade; Consumption-generated pollution; Trade policy; Commodity taxes

${ }^{*}$ Corresponding author: Department of Economics, Middle East Technical University (METU), Çankaya 06800, Ankara, Turkey. Tel: +(90) 312210 3046. Fax: +(90) 3122107964 . Email: koska@metu.edu.tr

${ }^{\dagger}$ Department of Economics, University of Tübingen, University of Adelaide, and CESifo, Germany.

${ }^{\ddagger}$ Department of Economics, Hacettepe University, Turkey. 


\section{Introduction}

This study employs a reciprocal dumping model of trade and scrutinizes the strategic role of commodity taxes and trade policy tools when environmental pollution is generated by final consumption of an imported product, and delineates the implications of domestic and foreign policy tools on countries' integration through international trade. The novel contribution of this paper is to focus on environmental degradation that is caused by final consumption of a product imported from a trading partner, which has been overlooked in the existing literature. The literature has almost exclusively focused on emissions from production and on how environmental tax policies affect competition among firms, international trade and firms' location choices, and social welfare. Statistical evidence, however, suggests that most industrialized countries have a larger $\mathrm{CO}_{2}$ footprint than their $\mathrm{CO}_{2}$ production, and that emissions from final consumption of imported products constitute a significantly large share of their total emissions. ${ }^{1}$ Bang et al. (2008) show that, in 2001, (i) the EU's consumption of goods and services generated 4,700 million tonnes of $\mathrm{CO}_{2}$ emissions, 500 million tonnes of which were generated mainly from imported products; (ii) while some countries (e.g., Latvia and Lithuania) have relatively low domestic emissions and large amounts embodied in their imports from the rest of the world (e.g., Russia), all OECD countries (except for Australia and Canada) have a $\mathrm{CO}_{2}$ consumption overshoot compared with production; and (iii) all EU countries have a $\mathrm{CO}_{2}$ consumption overshoot in their bilateral trade with China. A similar general picture exists as far as other pollutants (e.g., ground level ozone, or mercury emissions) are concerned; see Holladay (2008) for details.

The literature identifies different sources through which trade affects environmental pollution: (i) the scale effect that tends to increase pollution from production as a country's economic activity is expected to increase with trade; (ii) the technique effect that tends to improve environmental quality as demand for quality is expected to increase with trade; and (iii) the composition effect that tends to either increase or decrease environmental pollution with a net effect depending on how trade changes the composition of production and consumption (Grossman and Krueger, 1993; Copeland and Taylor, 1994; Antweiler et al., 2001). In a perfectly competitive trade model that incorporates environmental pollution (as measured by $\mathrm{SO}_{2}$ concentrations), Antweiler et al. (2001) find that trade liberalization reduces pollution. Frankel and Rose (2005) also find some evidence that openness to trade reduces pollution, as far as $\mathrm{SO}_{2}$ and $\mathrm{NO}_{2}$ emissions are concerned.

\footnotetext{
${ }^{1}$ Recent studies argue that indirect emissions from consumption should be considered when measuring emissions embodied in trade as indirect emissions are higher than direct ones, especially in developed countries (e.g., see, inter alia, Bang et al. 2008; Barrett et al., 2013; Marques et al., 2013; Sato, 2013).
} 
Following the seminal paper by Brander and Spencer (1984; 1985), a number of studies has applied the strategic trade policy analysis to the strategic environmental policy debate. In general, such studies employ oligopoly models of trade to examine the implications of unilateral environmental policies and show that non-cooperative Nash policies may lead to environmental dumping such that countries adopt laxer environmental policies. They may impose environmental taxes that are less than Pigouvian taxes (that is, the marginal tax rate is less than the marginal environmental damage), and such environmental taxes, together with import tariffs (e.g., as in Tanguay, 2001), may lead to a race to the bottom (in terms of environmental standards) and thus, welfare may deteriorate with trade liberalization. ${ }^{2}$ That said, Barrett (1994) indicates that the industry structure is also important, that is, if the industry is characterized by Bertrand oligopoly (price competition), rather than Cournot oligopoly (quantity competition), then the results are reversed, such that the unilaterally optimal environmental taxes are larger than the Pigouvian taxes. Moreover, the demand elasticity and the shape of the damage function are crucial in terms of welfare results.

The strategic use of tariffs and subsidies can be deemed to be rationalizable in oligopolistic markets. Countries, however, lose their degree of freedom in using such trade policy tools with their free trade agreements. Similarly, the strategic use of environmental policy instruments (if successfully enforced) may be effective when production is the main source of pollution, but they may not be applicable when consumption is considered to be the main source of pollution. ${ }^{3}$ As internationally traded commodities are taxed mostly where they are consumed (e.g., see McCracken and Stähler, 2010; McCracken, 2015), and as countries can freely set their commodity taxes, when consumption is the main source of externality, commodity taxes can be used strategically (just like the strategic use of trade policy tools) even in the case of a free trade agreement. The strategic role of commodity taxes as environmental instruments when consumption of an imported product generates pollution and the implications of the strategic use of this policy instrument on countries' integration through international trade have not yet received much attention in the literature. ${ }^{4}$ This study, thus, would like to make progress on this. In a simple intra-

\footnotetext{
${ }^{2}$ Eliminating trade policy tools and using environmental taxes (e.g., as in Walz and Wellisch, 1997; or as in Burquet and Sempere, 2003), or allowing for R\&D investments by firms responding to environmental standards (e.g., as in Ulph, 1996), however, may reduce incentives to adopt laxer environmental standards, and welfare may improve with trade liberalization.

${ }^{3}$ While different explanations may be offered, an obvious justification is the observation that environmental taxes are not used to discriminate products according to the source country.

${ }^{4}$ Considering consumption of a product that creates pollution, Copeland and Taylor (1995) show that the optimal policy will be a consumption tax that equals the marginal environmental damage, and that trade improves welfare especially if there exists a perfectly costless institutional structure with well intentions. Though it is worth noting that their analysis focuses on a competitive framework.
} 
industry trade model with imperfect competition, this study scrutinizes the strategic role of trade and commodity taxes as environmental instruments and demonstrates that the externality generated by consumption of an imported good, as measured by countries' marginal disutility from pollution, can have detrimental effects on countries' economic integration. Our results suggest that while a substantially large marginal disutility from pollution can interrupt bilateral trade and cross-hauling can cease to exist, in the case of a sufficiently small marginal disutility from pollution, both trade and commodity taxes are deemed necessary so as to effectively address pollution. The tax rates, however, are less than Pigouvian taxes due to Cournot competition. For sufficiently small values of the marginal disutility from pollution, the country claiming responsibility for pollution prefers commodity taxes over import tariffs, and compared to the case of trade policies, free trade can be maintained for larger values of the marginal disutility from pollution when commodity taxes are used strategically as environmental instruments.

The remainder of the paper is organized as follows. Section 2 introduces the model, and scrutinizes the welfare implications of imposing import tariffs when consumption of an imported product generates pollution. Section 3 looks at consumption-generated pollution under free trade, and discusses the welfare implications. Section 4 analyzes the implications of the use of commodity taxes as environmental instruments, and compares the results with those discussed in Sections 2 and 3. Section 5 offers some concluding remarks. For convenience, most of the proofs and technical details have been relegated to the Appendix.

\section{The model}

Following the seminal paper by Brander and Krugman (1983), we employ a simple model of intra-industry trade, and examine the nexus between trade and the environment. We consider two countries, Home and Foreign, which are identical with respect to consumers' preferences and market size, and two firms (one in each country), which are identical with respect to production technology and costs, and which produce a homogeneous good with zero marginal cost and compete by quantities against each other in both countries. The inverse demand function in country $i$ is given by $p_{i}=a-b Q_{i}, i=\{h, f\}$, where $h$ and $f$ stand for Home and Foreign, respectively; $p_{i}$ is the price of the homogeneous good in country $i$; $a$ and $b$ denote market size and the slope of the inverse demand function, respectively; and $Q_{i}=x_{i}+y_{i}$ is the aggregate output in country $i$, such that $y_{i}$ is the local production in country $i$ and $x_{i}$ is country $i$ 's imports from the other country. Markets are segmented such that each firm considers each country as a separate market. 
In this section, we focus on the case of no free trade agreement between the two countries, and thus trade may be subject to tariffs. Without loss of generality, we assume away transport costs of exporting/importing throughout the analysis. We consider a simple, two-stage, non-cooperative game. In the first stage, the governments decide on their import tariffs that maximize their local welfare. Let $t_{h}$ and $t_{f}$ denote the tariff rates imposed by Home and Foreign, respectively. In the second stage, given the tariff rates, the firms compete against each other by quantities in both countries, such that each firm simultaneously, and non-cooperatively, decides on the outputs that maximize profits in both markets. Firm $i$ that locates in country $i$ and exports to country $j, i, j=\{h, f\}, i \neq$ $j$, will earn aggregate profits, denoted $\pi_{i}$, that is the sum of the profits from the domestic and the foreign market. We solve the game backwards such that we start from the second stage (the Cournot game between the two firms) and search for the subgame perfect Nash equilibrium. The maximization problem of firm $i$ is

$$
\max _{\left\{x_{j} \geq 0, y_{i} \geq 0\right\}} \pi_{i}=p_{i} y_{i}+\left(p_{j}-t_{j}\right) x_{j} ; i, j=\{h, f\}, i \neq j .
$$

From the first-order conditions, we find that the (optimal) outputs supplied to country $i$ by (from country $i$ 's perspective) the foreign firm and the domestic firm are, respectively,

$$
\begin{aligned}
& x_{i}= \begin{cases}\left(a-2 t_{i}\right) / 3 b & \text { if } 0 \leq t_{i}<a / 2 \\
0 & \text { if } t_{i} \geq a / 2\end{cases} \\
& y_{i}=\frac{a+t_{i}}{3 b}, \quad \text { where } i=\{h, f\} .
\end{aligned}
$$

Using the expressions for the optimal outputs, given by equation (1), we can derive the aggregate profits for each firm such that

$$
\pi_{i}=\underbrace{b y_{i}^{2}}_{\begin{array}{c}
\text { Profits from } \\
\text { local sales }
\end{array}}+\underbrace{b x_{j}^{2}}_{\begin{array}{c}
\text { Profits from } \\
\text { exports }
\end{array}} ; i, j=\{h, f\}, i \neq j,
$$

where $x$ and $y$ are given by equation (1). In the first stage of the game, each government unilaterally decides on its import tariff rate that maximizes its local welfare, which we will refer to as Nash (non-cooperative) trade policies. Country i's welfare can be expressed as the sum of the domestic firm's profits (from both local sales and exports) $\pi_{i}$, consumer surplus $b\left(x_{i}+y_{i}\right)^{2} / 2$, tariff revenues $t_{i} x_{i}$, and disutility from environmental pollution.

To simplify the analysis and to focus on pollution triggered by a country's consumption of a good imported from a foreign country, we assume that (i) Home's consumption of the good produced in Foreign is the only source of pollution; (ii) pollution depends linearly on the level of Home's imports and is perceived by consumers as exogenous such that consumers do not take into account environmental damage their consumption of the imported good might have caused; and (iii) Home takes full responsibility of such 
pollution, and there is constant marginal disutility from pollution, denoted by $\delta$, such that Home's local welfare decreases by $\delta x_{h}, \delta>0$; and finally (iv) Foreign does not claim responsibility for any activity that might have caused pollution. To summarize, Home and Foreign choose their unilateral tariff rates $t_{h}$ and $t_{f}$ to maximize, respectively,

$$
\begin{aligned}
& W_{h}^{t}=\pi_{h}+\frac{b\left(x_{h}+y_{h}\right)^{2}}{2}+\left(t_{h}-\delta\right) x_{h}, \\
& W_{f}^{t}=\pi_{f}+\frac{b\left(x_{f}+y_{f}\right)^{2}}{2}+t_{f} x_{f}
\end{aligned}
$$

where the optimal outputs, $x_{i}$ and $y_{i}$, and the maximized profits, $\pi_{i}, i=\{h, f\}$, are given by equations (1) and (2), respectively, and where superscript $t$ denotes the case that the two countries adopt Nash trade policies. Differentiating $W_{h}^{t}$ and $W_{f}^{t}$, given by equation (3), w.r.t. $t_{h}$ and $t_{f}$, respectively, and setting the results equal to zero (i.e., $\left.\partial W_{i}^{t}(\mathbf{t}) / \partial t_{i}=0, i=\{h, f\}\right)$ and solving for $t_{h}$ and $t_{f}$ yield the welfare-maximizing tariff rates such that ${ }^{5}$

$$
t_{h}^{*}=t_{f}^{*}+\frac{2}{3} \delta=\underbrace{\frac{a}{3}}_{\begin{array}{c}
\text { Optimal tariff } \\
\text { (no disutility) }
\end{array}}+\underbrace{\frac{2}{3} \delta}_{\begin{array}{c}
\text { Environmental } \\
\text { protection }
\end{array}} .
$$

As is clear from equation (4), in the presence of consumption-generated pollution, Home's optimal tariff rate exceeds Foreign's tariff rate.

Proposition 1 When countries adopt Nash trade policies, and when the only source of pollution is consumption of the good imported from a trading partner, the country that claims responsibility for pollution attempts to internalize the externality by increasing the tariff rate above the optimal level that would maximize local welfare had there been no consumption-generated pollution, although the increase in the per-unit tariff rate is less than the marginal disutility from pollution.

The following remarks are in order. For any given Foreign tariff rate, increasing the tariff rate in Home (within the relevant range $t_{h}^{*}<a / 2$ as is given by equation (1a)) increases the local firm's aggregate profits by increasing its domestic market share. Aggregate consumption in Home, however, decreases as the decrease in imports is more than the increase in local sales, and thus consumer surplus decreases. Although increasing the tariff rate in Home decreases imports, and thus pollution decreases (and so does disutility from environmental degradation), tariff revenues also decrease, leading Home to compromise and increase the per-unit tariff rate by less than the marginal disutility from pollution. The implicit assumption here is that cross-hauling exists, that is, the marginal disutility

\footnotetext{
${ }^{5}$ Note that $D_{t}^{2} W^{t}(\mathbf{t})$ is negative definite implying that the objective function is strictly concave, that is, the sufficient condition for a unique maximum, $\mathbf{t}^{*}=\operatorname{argmax} W^{t}(\mathbf{t})$, is fulfilled.
} 
from pollution is sufficiently small $(\delta<a / 4)$ such that the tariff rate maximizing Home's welfare is still less than the prohibitive tariff rate (i.e., $(a+2 \delta) / 3<a / 2)$.

Lemma 1 An increase in the marginal disutility from pollution interrupts trade such that cross-hauling will cease to exist, and there will be only one-way trade.

A sufficiently large marginal disutility from pollution (i.e., $\delta>a / 4$ ) leads Home to impose a tariff above the prohibitive rate, in which case exporting is not profitable for the firm located in Foreign, while exporting to Foreign will still be profitable for the firm located in Home. In the next section, we scrutinize the question whether a free trade agreement between Home and Foreign would improve welfare, and under which circumstances both countries would have an incentive to engage in free trade.

\section{Consumption-generated pollution under free trade}

In this section, we first look at the case of autarky in both countries such that firms have monopoly power in their respective domestic markets. In such a situation, each firm is active only in the domestic market, produces at the monopoly level for this market (i.e., $x_{i}=0$, and $y_{i}=a / 2 b, i=\{h, f\}$ ), and earns monopoly profits (i.e., $\pi_{i}=b(a / 2 b)^{2}$, $i=\{h, f\})$. There is no trade, and thus no tariff revenue in either country, nor is there environmental pollution for which Home has to claim responsibility. Using equation (3), it is straightforward to show that $W_{i}^{* a}=3 a^{2} / 8 b, i=\{h, f\}$, provided Foreign does not take into account potential pollution from its local production/consumption activities. Note that superscript $a$ stands for autarky.

In case of a free trade agreement between these two countries (moving from autarky), market competition increases, decreasing the two firms' market share in their respective domestic markets (moving from monopoly to international duopoly), while each firm shares the market across borders such that $x_{i}=y_{i}=a / 3 b, i=\{h, f\}$. This implies an increase in each firm's aggregate profits, and an increase in total consumption in each country. Welfare would improve in both countries when moving from autarky to free trade had there been no pollution such that $W_{i}^{* f t}(\delta=0)=4 a^{2} / 9 b>W_{i}^{* a}=3 a^{2} / 8 b, i=\{h, f\}$, where superscript $f t$ stands for free trade. In case of pollution from consumption of an imported good, however, this result does not hold as welfare decreases due to disutility from pollution, especially in the country (Home) that claims responsibility such that

$$
W_{h}^{* f t}=\underbrace{\left(\frac{4 a^{2}}{9 b}\right)}_{\begin{array}{c}
\text { Welfare } \\
\text { (no disutility) }
\end{array}}-\underbrace{\delta\left(\frac{a}{3 b}\right)}_{\begin{array}{c}
\text { Disutility } \\
\text { (pollution) }
\end{array}} .
$$


Comparing equation (5) with autarky welfare immediately leads to

Proposition 2 The country claiming responsibility for pollution will have no unilateral incentive to move from autarky to free trade if its consumption of the imported good generates pollution, and if the marginal disutility from pollution is sufficiently large.

Free trade decreases local sales and increases imports (which increase pollution from consumption). Although free trade increases both total consumption in a given country and the aggregate profits of a given firm, with which welfare increases, a sufficiently large marginal disutility from pollution (i.e., $\delta>5 a / 24$ ) leads welfare to decrease by more than gains from free trade. Note that free trade does not leave any room for a trade policy that could internalize the negative externality of consuming the imported good. As for the country that is not concerned about pollution (Foreign), moving from autarky to free trade always improves welfare. In the case that Home does not allow for imports from Foreign (i.e., $\delta>5 a / 24$ ), Foreign will be better off by opening its market to trade and by imposing an import tariff (as compared to autarky and to the case it allows Home to export to its market freely). The intuition is that, in the case of one-way trade (from Home to Foreign), imposing a tariff not only generates additional revenues, but also increases the domestic firm's market share (as compared to the case of oneway free trade). There exists an optimal import tariff rate $\left(t_{f}=a / 3\right)$ at which welfare is maximized such that the decrease in welfare due to a decrease in total consumption (with an import tariff) is overcompensated by the increase in welfare due to an increase in the domestic firm's profits and in tariff revenues. Also, as compared to autarky, Home will be better off in such a situation, because there will be no change in consumption, nor will there be disutility from pollution generated by consumption of the imported good, yet it will export to Foreign, which will increase the local firm's profits. It is now clear that the size of the marginal disutility from pollution generated by consumption of the imported good may lead to different equilibrium trade regimes:

Proposition 3 A sufficiently large marginal disutility from pollution (i.e., $\delta>a / 4$ ) leads to one-way trade (from Home to Foreign) that is subject to an import tariff imposed by Foreign. If, however, the marginal disutility from pollution takes some intermediate

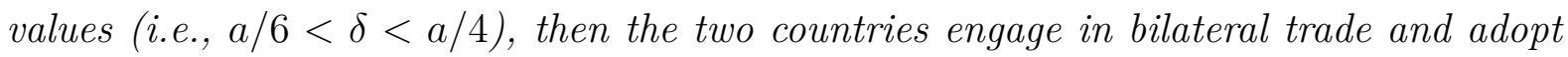
Nash trade policies. Free trade can be maintained only if the marginal disutility from pollution is sufficiently small (i.e., $\delta<a / 6$ ).

Proof. See Appendix A.1.

Following Proposition 3, one empirical prediction of the model could be that one-way trade among some countries may be explained by asymmetric perceptions over pollution 
from consumption of a traded good, and that the size of the marginal disutility from pollution (or rather, the level of responsibility taken by the country triggering pollution due to meeting some of its local demand by imports) may be at a level that may hinder international trade. Moreover, Nash trade policies become important in the presence of pollution, as they may be used not only to generate tariff revenues, to increase the domestic firm's market share, and to correct domestic distortions, but also to restrict imports so as to decrease pollution generated by consumption of the imported good. That said, attempts to produce goods such that consumption generates less pollution may be argued not only to contribute to reduce environmental pollution, but also to increase the volumes of trade and gains from trade.

\section{Commodity taxes as environmental instruments}

In this section, we turn our attention to domestic policies, especially in case of free trade. Hence, we scrutinize commodity taxes employed as environmental instruments in the absence of environmental taxes. As commodity taxes are non-discriminatory, and apply to both domestic consumption and consumption of imports, we assume away environmental (consumption) taxes that may discriminate products according to the source country. As in the preceding sections, we consider a two-stage non-cooperative game between firms, and between governments, and solve the game backwards for the subgame perfect Nash equilibrium. In the first stage, governments now decide on their commodity taxes that maximize their local welfare. We denote by $\tau_{h}$ and $\tau_{f}$, commodity taxes imposed by Home and Foreign, respectively. Firms take commodity taxes as given, and decide on their outputs (both for the domestic and the foreign market) that maximize the profits in both markets. Once again, let $\pi_{i}$ denote the aggregate profits (the sum of the profits from the domestic and the foreign market) of the firm that locates in country $i$ and exports to country $j, i, j=\{h, f\}, i \neq j$. The maximization problem of the firms is now

$$
\max _{\left\{x_{j} \geq 0, y_{i} \geq 0\right\}} \pi_{i}=\left(p_{i}-\tau_{i}\right) y_{i}+\left(p_{j}-\tau_{j}\right) x_{j} ; i, j=\{h, f\}, i \neq j
$$

From the first-order conditions, we find that the (optimal) outputs supplied to country $i$ by (from country $i$ 's perspective) the domestic firm and the foreign firm are, respectively,

$$
y_{i}=x_{i}=\left\{\begin{array}{ll}
\left(a-\tau_{i}\right) / 3 b & \text { if } 0 \leq \tau_{i}<a \\
0 & \text { if } \tau_{i} \geq a
\end{array} ; i=\{h, f\} .\right.
$$

Using the expressions for the optimal outputs, given by equation (6), we can derive the aggregate profits for each firm as in equation (2), where $x$ and $y$ are now given by equation (6). In the first-stage of the game, each government unilaterally decides on the commodity 
tax rate that maximizes its local welfare, which we refer to as Nash (non-cooperative) domestic policies. As in the preceding sections, country $i$ 's welfare can expressed as the sum of the domestic firm's aggregate profits $\pi_{i}$, given by equation (2), consumer surplus $b\left(x_{i}+y_{i}\right)^{2} / 2$, where $y_{i}$ and $x_{i}$ are given by equation (6), and tax revenues, $\tau_{i}\left(x_{i}+y_{i}\right)$. In addition, Home takes into account disutility from environmental pollution. Home and Foreign choose the tax rates $\tau_{h}$ and $\tau_{f}$ to maximize, respectively,

$$
\begin{aligned}
& W_{h}^{\tau}=\pi_{h}+\frac{b\left(x_{h}+y_{h}\right)^{2}}{2}+\tau_{h}\left(x_{h}+y_{h}\right)-\delta x_{h}, \\
& W_{f}^{\tau}=\pi_{f}+\frac{b\left(x_{f}+y_{f}\right)^{2}}{2}+\tau_{f}\left(x_{f}+y_{f}\right),
\end{aligned}
$$

where superscript $\tau$ denotes the case that the two countries adopt Nash domestic policies (commodity taxes). Differentiating $W_{h}^{\tau}$ and $W_{f}^{\tau}$, given by equation (7), w.r.t. $\tau_{h}$ and $\tau_{f}$, respectively, and setting the results equal to zero (i.e., $\partial W_{i}^{\tau}(\boldsymbol{\tau}) / \partial \tau_{i}=0, i=\{h, f\}$ ), and solving for $\tau_{h}$ and $\tau_{f}$ yield the welfare-maximizing commodity tax rates such that ${ }^{6}$

$$
\underbrace{\tau_{h}^{*}=\frac{\delta}{2}}_{\begin{array}{c}
\text { Environmental } \\
\text { protection }
\end{array}}>\underbrace{\tau_{f}^{*}=0}_{\begin{array}{c}
\text { Optimal tax } \\
\text { (no disutility) }
\end{array}}, \text { for any } \delta>0 .
$$

As is clear from equation (8), if there is no pollution from consumption of the imported good (i.e., if $\delta=0$ ), or if a country does not claim any responsibility for pollution (as in Foreign), then the optimal (non-discriminatory) commodity tax rate is equal to zero. The reason is that, for any given commodity tax rate imposed by the other country, increasing the tax rate (imposing a positive tax rate) generates positive tax revenues for the government, with which local welfare increases. That said, a positive commodity tax increases the market price and decreases local consumption, and both consumer surplus and the domestic firm's profits from local sales decrease, with which local welfare decreases. These effects of a positive commodity tax, however, cancel out each other (the profit-shifting incentive and the incentive for domestic correction eliminate each other) especially in the case of a linear inverse demand function. If, however, consumption of the imported good triggers pollution and the importing country takes full responsibility of such pollution - if $\delta>0$ - (as in Home), then there is an additional incentive to impose a positive commodity tax rate, which is the incentive for environmental correction that attempts to internalize negative consumption externality.

Proposition 4 When countries adopt only Nash domestic policies (commodity taxes), and when the only source of pollution is consumption of the good imported from a trading partner, the country that claims responsibility for pollution attempts to internalize the

${ }^{6}$ Note that $D_{\tau}^{2} W^{\tau}(\boldsymbol{\tau})$ is negative definite implying that the objective function is strictly concave, that is, the sufficient condition for a unique maximum, $\boldsymbol{\tau}^{*}=\operatorname{argmax} W^{\tau}(\boldsymbol{\tau})$, is fulfilled. 
externality by imposing a positive commodity tax rate, which would not be optimal had there been no consumption-generated pollution. The optimal tax rate is, however, less than the marginal disutility from pollution.

Note that in both Nash trade and domestic policies (import tariffs and commodity taxes), the incentive for domestic correction of distortions is present. Using Nash trade policies, governments shift profits not only from foreign firms to their treasury via tariff revenues, but also from foreign firms to domestic firms, which is mainly due to Cournot competition. Using Nash domestic policies, however, the domestic country shifts profits from both the domestic and foreign firms to its treasury via tax revenues (provided the policy tool is nondiscriminatory), that is, consumption of both the locally-produced and the imported good decreases, only the latter of which, however, increases welfare via decreasing disutility from pollution in addition to positive tax revenues.

We can compute the maximized welfare levels, $W_{h}^{* \tau}$ and $W_{f}^{* \tau}$, by substituting the optimal commodity tax rates, given by equation (8), back into the welfare expressions, given by equation (7). Comparing $W_{h}^{* f t}$, given by equation (5), and $W_{h}^{* \tau}$, we can show that the optimal commodity tax rate imposed by Home decreases pollution by decreasing consumption and increases local welfare above the level that would have been maintained had there been free trade and no commodity taxes imposed $\left(W_{h}^{* \tau} \geq W_{h}^{* f t}\right.$ for any $\delta$ : $\left.\delta \geq 0 \mid W^{*} \in \mathbb{R}_{+}^{2}\right)$ such that

$$
W_{h}^{* \tau}=\underbrace{W_{h}^{* f t}}_{\begin{array}{c}
\text { Welfare under } \\
\text { free trade } \\
\text { (no tariffs/taxes) }
\end{array}}+\underbrace{\left(\frac{\delta^{2}}{12 b}\right)}_{\begin{array}{c}
\text { Gains from } \\
\text { commodity taxes }
\end{array}} .
$$

It is straightforward to show that commodity taxes imposed by Home decreases welfare in Foreign and that if the marginal disutility from pollution is sufficiently large (i.e., $\delta>2 a$ ), then Home's optimal tax rate exceeds the prohibitive tax rate (see equation (6)), in which case consumption ceases to exist in Home, while there will be one-way trade (from Home to Foreign). In such a situation, autarky stands out as the safe resort. Proposition 2 has shown that the country that triggers pollution by its consumption of the imported good will have no unilateral incentive to move from autarky to free trade if it claims full responsibility for pollution, provided the size of the marginal disutility from pollution is sufficiently large such that $\delta>5 a / 24$. Following Proposition 2 and equation (9), we can show that free trade can be maintained not only when $\delta \leq 5 a / 24$ (in which case the country claiming responsibility for consumption-generated pollution imposes a positive commodity tax rate) but also when $\delta>5 a / 24$ such that

Proposition 5 Provided that Nash domestic policies are available, (compared to the case of Nash trade policies) free trade can be maintained also for larger values of the marginal 
disutility from pollution such that $5 a / 24<\delta=2 \tau_{h}^{*}<\hat{\delta}$ (for which free trade would not have improved welfare as compared to autarky in the absence of commodity taxes as environmental instruments).

\section{Proof. See Appendix A.1 and Appendix A.2.}

The intuition is as follows. In the case of Nash trade policies, the country claiming full responsibility for pollution (Home) loses its strategic environmental instrument whenever it engages in free trade, whereas in the case of Nash domestic policies, commodity taxes substituting environmental instruments can still be used under free trade. That is, as compared to Nash trade policies (import tariffs), Nash domestic policies (commodity taxes) allow for a wider range of the marginal disutility from pollution, within which free trade yields higher welfare than autarky. Moreover, if we consider the equilibrium trade regime that will be maintained for a given marginal disutility from pollution, Nash trade policies lead to even a smaller range $(0<\delta<a / 6$; see Proposition 3$)$, within which free trade will be the equilibrium trade regime, whereas free trade (with a positive commodity tax imposed by Home) will be maintained under Nash domestic policies whenever $\delta<\hat{\delta}$ where $a / 6<\hat{\delta} .^{7}$ It is now clear from Propositions 2,3 and 5 that

Proposition 6 For sufficiently small values of the marginal disutility from pollution, the country claiming responsibility for pollution (Home) prefers Nash domestic policies (commodity taxes) over Nash trade policies (import tariffs), whereas for sufficiently high values of the marginal disutility from pollution, this policy preference is reversed.

\section{Proof. See Appendix A.2.}

Although Nash domestic policies increase the range of the marginal disutility from pollution, within which free trade can be maintained in equilibrium, they are less effective for sufficiently high values of the marginal disutility from pollution. If the marginal disutility from pollution is sufficiently small such that free trade can be maintained in equilibrium, imposing a positive commodity tax will not much distort local consumption (as the tax rate will be sufficiently small), while it will effectively decrease pollution via decreasing consumption of the imported good. If, however, the marginal disutility from pollution is sufficiently large such that free trade cannot be maintained in equilibrium, then countries either engage in (one-way or bilateral) trade and impose positive import tariffs under Nash trade policies, or stay in autarky under Nash domestic policies. In such a situation, they will prefer trade under Nash trade policies.

\footnotetext{
${ }^{7}$ Note that Foreign's welfare under free trade (with a positive commodity tax imposed by Home) is larger than its welfare under autarky, for any $\delta \leq 0.77$ (see Appendix A.2).
} 


\section{Concluding remarks}

In a simple reciprocal dumping model of trade, this study has scrutinized the strategic role of trade and commodity taxes as environmental instruments. The main contribution of this study is the source of environmental pollution that is consumption of an imported good from a trading partner. Although statistical evidence shows that consumptiongenerated pollution constitutes a significantly large share of most industrialized countries' total emissions, the related literature has almost exclusively taken on board production as the main source of pollution and studied the strategic use of environmental policy instruments. If, however, a country's consumption of an imported good triggers pollution, for which the country claims full responsibility, then environmental taxes may not be used, especially when discriminating products via taxes according to the source country is not applicable. In such a situation, trade and commodity taxes become important and can crucially affect trade patterns, as they can be used not only to generate tax revenues, to increase the domestic firm's market share, and to correct domestic distortions, but also to internalize the negative consumption externality.

According to our results, while a sufficiently large marginal disutility from pollution interrupts bilateral trade, for sufficiently small values of the marginal disutility from pollution, the country claiming responsibility for pollution prefers commodity taxes over import tariffs, and compared to the case of trade policies, free trade can be maintained for larger values of the marginal disutility from pollution when commodity taxes are used strategically as environmental instruments. An implicit assumption of the model is that the countries are allowed to adopt only a single policy instrument at any given time, such that they either impose an import tariff or a non-discriminatory commodity tax. The reason is that in case if they are allowed to use both import tariffs and commodity taxes at the same time, then the optimal solution is such that both countries impose positive import tariffs above the prohibitive rate so as to ensure there is no trade, and they subsidize local consumption (impose negative commodity taxes) such that the first-best is attained with no further insight; see Koska and Stähler (2016) for details.

\section{Appendix A}

\section{A.1 Nash Trade Policies and the Equilibrium Trade Regime}

As is already discussed, in the case that the two countries adopt Nash trade policies and there is bilateral trade between these two countries, the optimal outputs, $x_{i}$ and $y_{i}$, and 
the maximized profits, $\pi_{i}, i=\{h, f\}$, are given by equations (1) and (2), respectively, and the optimal tariff rates, $t_{i}^{*}, i=\{h, f\}$, that maximize welfare, $W_{i}, i=\{h, f\}$, are given by equation (4). Substituting the optimal outputs, $x_{i}$ and $y_{i}$, the maximized profits, $\pi_{i}$, $i=\{h, f\}$, and the optimal tariff rates, $t_{i}^{*}, i=\{h, f\}$, back into the welfare expressions given by equation (3) yields the maximized welfare levels, denoted $W_{i}^{* t}, i=\{h, f\}$, where superscript $t$ stands for the case that the two countries impose tariffs and trade, such that

$$
\begin{aligned}
& W_{h}^{* t}=\frac{65 a^{2}-18 a \delta+36 \delta^{2}}{162 b}, \\
& W_{f}^{* t}=\frac{65 a^{2}-16 a \delta+32 \delta^{2}}{162 b} .
\end{aligned}
$$

If, however, the two countries engage in free trade (i.e., $t_{i}=0, i=\{h, f\}$ ), then the maximized welfare levels, denoted $W_{i}^{* f t}$, are given by equation (5). If there is autarky in both countries, then the maximized welfare levels are $W_{i}^{* a}=3 a^{2} / 8 b, i=\{h, f\}$.

In the case of one-way trade (from Home to Foreign), we have already shown that Foreign is always better off by imposing an import tariff, $t_{f}^{*}=a / 3$, in which case the maximized welfare levels in Home and in Foreign are $W_{h}^{* a t}=251 a^{2} / 648 b$ and $W_{f}^{* a t}=7 a^{2} / 18 b$, respectively, where superscript at stands for the regime in Home (autarky) and in Foreign (trade with an import tariff), respectively. We will distinguish between two cases.

Case 1: The two countries are initially adopting Nash trade policies.

As is already discussed, if the marginal disutility from pollution is sufficiently large such that $\delta>a / 4$, Home's tariff rate becomes larger than the prohibitive tariff rate implying that cross-hauling will cease to exist, and there will be only one-way trade (from Home to Foreign), in which case Foreign will impose an import tariff, $t_{f}^{*}=a / 3$. Although Foreign would be better off had there been a free trade agreement $\left(W_{f}^{* f t}>W_{f}^{* a t}>W_{f}^{* a}\right)$, especially as compared to one-way trade (with foreign import tariffs), or to autarky, Home would refuse to engage in free trade in such a situation since $\delta>a / 4$ at which $W_{h}^{* a t}>W_{h}^{* f t}$. Therefore, in equilibrium, we will observe no cross-hauling, but one-way trade under Nash policy if $\delta>a / 4$ because Foreign is better off with one-way trade when it imposes an import tariff as compared to the no-tariff case, and is better off in autarky as compared to the case of one-way trade without an import tariff.

Suppose now the marginal disutility from pollution is such that $a / 6<\delta<a / 4$, that is, Home's tariff rate is less than the prohibitive tariff rate. The question is whether the countries have unilateral incentives to abolish tariff rates and engage in free trade, in such a situation. Although Foreign welfare would improve had there been a free trade agreement (given $\delta<a / 4, W_{f}^{* f t}>W_{f}^{* t}$ ), the marginal disutility from pollution is still too large such that Home is better off by adopting Nash trade policies. If, however, the marginal disutility from pollution is sufficiently small $(\delta<a / 6)$, then both countries will 
have an incentive to abolish tariffs and engage in free trade since $W_{i}^{* f t}>W_{i}^{* t}, i=\{h, f\}$, provided $\delta<a / 6$. Note that, autarky in both countries would not emerge in equilibrium in any of the cases discussed above.

Case 2: The two countries are initially in autarky.

As is already shown by Proposition 2, Home has no unilateral incentive to move from autarky to free trade when the marginal disutility from pollution is sufficiently large such that $\delta>5 a / 24$. Also, as is already discussed, Foreign is always better off by opening its market to trade and by imposing an import tariff, as compared to autarky. It is also straightforward to show that welfare improves in Home $\left(W_{h}^{* t}>W_{h}^{* a}\right)$ should it open its market to trade and adopt Nash trade policies. As we have already discussed above, as compared to free trade in both countries, Nash trade policies improve welfare in Home if $\delta>a / 6$. Therefore, given $a / 6<\delta<a / 4$, free trade will not emerge in equilibrium, but both countries will open their markets to trade and will adopt Nash trade policies. As for $\delta>a / 4$, it is clear from equations (1) and (4), and from Lemma 1 that Home's tariff rate will be larger than the prohibitive tariff rate, in which case we will observe only one-way trade, that is, from Home to Foreign. Not surprisingly, a successful free trade agreement between Home and Foreign will be maintained if the marginal disutility from pollution is sufficiently small such that $\delta<a / 6$.

\section{A.2 Commodity Taxes and the Equilibrium Trade Regime}

In the case that the two countries adopt Nash domestic policies, the optimal outputs, $x_{i}$ and $y_{i}$, and the maximized profits, $\pi_{i}, i=\{h, f\}$, are given by equations (6) and (2), respectively, and the optimal commodity tax rates, $\tau_{i}^{*}, i=\{h, f\}$, that maximize welfare, $W_{i}^{\tau}, i=\{h, f\}$, are given by equation (8). Substituting the optimal outputs, $x_{i}$ and $y_{i}$, the maximized profits, $\pi_{i}, i=\{h, f\}$, and the optimal tariff rates, $\tau_{i}^{*}, i=\{h, f\}$, back into the welfare expressions given by equation (7) yields the maximized welfare levels, denoted $W_{i}^{* \tau}, i=\{h, f\}$, where superscript $\tau$ stands for the case that the two countries adopt Nash domestic policies and impose non-discriminatory commodity taxes, such that

$$
\begin{aligned}
& W_{h}^{* \tau}=\frac{16 a^{2}-12 a \delta+3 \delta^{2}}{36 b}, \\
& W_{f}^{* \tau}=\frac{16 a^{2}-4 a \delta+\delta^{2}}{36 b} .
\end{aligned}
$$

If, however, the two countries engage in free trade, and impose no tax/tariff (i.e., $\tau_{i}=$ $\left.t_{i}=0, i=\{h, f\}\right)$, then the maximized welfare levels, denoted $W_{i}^{* f t}, i=\{h, f\}$, are 
given by equation (5). We can rewrite equations (A.2a) and (A.2b) such that

$$
\begin{aligned}
& W_{h}^{* \tau}=W_{h}^{* f t}+\frac{\delta^{2}}{12 b}, \\
& W_{f}^{* \tau}=W_{f}^{* f t}-\frac{\delta(4 a-\delta)}{36 b},
\end{aligned}
$$

which imply that the country claiming responsibility for consumption-generated pollution (Home) is always better off as compared to free trade by imposing a positive commodity tax rate under free trade, whereas the country taking no responsibility for pollution (Foreign) is worse off as compared to free trade when Home imposes a positive commodity tax rate. We can compare autarky welfare and welfare under free trade (subject to a positive commodity tax rate imposed only by Home), and show that

$$
\lim _{\delta \rightarrow \hat{\delta}^{\prime}} W_{h}^{* \tau}=\lim _{\delta \rightarrow \delta^{\prime}} W_{f}^{* \tau}=W_{i}^{* a}, \quad i=\{h, f\}
$$

where $\hat{\delta} \simeq 0.220487 a$ and $\delta^{\prime} \simeq 0.775255 a>\hat{\delta}$, and that $W_{h}^{* \tau}>W_{h}^{* a}$ if and only if $\delta<\hat{\delta}$, and $W_{f}^{* \tau}>W_{f}^{* a}$ if and only if $\delta<\delta^{\prime}$, because $\partial\left[W_{h}^{* \tau}-W_{h}^{* a}\right] / \partial \delta<0$ and $\partial\left[W_{f}^{* \tau}-W_{f}^{* a}\right] / \partial \delta<0$ for any $\delta<2 a$. It is now clear that for a sufficiently small marginal disutility from pollution such that $\delta<\hat{\delta}$, free trade can be maintained because the two countries can improve welfare under free trade (as compared to autarky), provided a positive commodity tax rate is imposed by Home (Proposition 5).

Proposition 3 and Appendix A.1 have already shown that whenever the marginal disutility from pollution is sufficiently small such that $\delta<a / 6$, free trade is maintained in the case of Nash trade policies (import tariffs), in which case the country claiming responsibility for consumption-generated pollution (Home) is unambiguously better off by imposing a positive (non-discriminatory) commodity tax rate $\left(W_{h}^{* \tau}>W_{h}^{* f t}\right)$ so as to internalize the negative consumption externality. If, however, $a / 6<\delta<\hat{\delta}$, the two countries engage in trade and impose positive import tariffs in equilibrium (Home internalizes the negative consumption externality by imposing a higher tariff rate than Foreign) under Nash trade policies (Proposition 3 and Appendix A.1), whereas free trade (subject to a positive commodity tax rate imposed only by Home) is the equilibrium trade regime under Nash domestic policies. In such a case, we can show that

$$
\begin{aligned}
\lim _{\delta \rightarrow \tilde{\delta}}\left[W_{h}^{* \tau}-W_{h}^{* t}\right] & =\lim _{\delta \rightarrow \tilde{\delta}}\left[\frac{14 a^{2}-72 a \delta-45 \delta^{2}}{324 b}\right]=0, \\
\lim _{\delta \rightarrow \delta^{\prime \prime}}\left[W_{f}^{* \tau}-W_{f}^{* t}\right] & =\lim _{\delta \rightarrow \delta^{\prime \prime}}\left[\frac{14 a^{2}-4 a \delta-55 \delta^{2}}{324 b}\right]=0,
\end{aligned}
$$

where $\tilde{\delta} \simeq 0.175249 a<\hat{\delta}$ and $\delta^{\prime \prime} \simeq 0.46947 a<\delta^{\prime}$, and that $W_{h}^{* \tau}>W_{h}^{* t}$ if and only if $\delta<\tilde{\delta}$, and $W_{f}^{* \tau}>W_{f}^{* t}$ if and only if $\delta<\delta^{\prime \prime}$, because $\partial\left[W_{h}^{* \tau}-W_{h}^{* t}\right] / \partial \delta<0$ and $\partial\left[W_{f}^{* \tau}-W_{f}^{* t}\right] / \partial \delta<0, \forall \delta$. Therefore, the equilibrium trade regime under Nash domestic 
policies leads to higher welfare for both countries than that under Nash trade policies, if and only if $a / 6<\delta<\tilde{\delta}$.

If, however, $\tilde{\delta}<\delta<\hat{\delta}$, then Home is better off under Nash trade policies, whereas Foreign is better off under Nash domestic policies. In such a situation, we can show that (i) if the two countries are initially under autarky, free trade (with or without commodity taxes) cannot be maintained in equilibrium, because the marginal disutility from pollution is sufficiently large such that Home would not accept to engage in free trade, but rather would like to engage in trade and to restrict imports from Foreign by imposing a positive import tariff, which would lead the two countries to trade and impose positive import tariffs; and (ii) if the two countries are initially trade partners, and are currently imposing import tariffs, Home would not accept to abolish tariffs and engage in free trade (with or without commodity taxes).

Finally, if the marginal disutility from pollution is sufficiently large such that $\delta>\hat{\delta}$, then the equilibrium trade regime under Nash trade policies (cross-hauling subject to positive import tariffs if $\hat{\delta}<\delta<a / 4$, or one-way trade subject to a positive import tariff imposed by Foreign if $\delta>a / 4$ ) leads to higher welfare for both countries than that under Nash domestic policies, that is, autarky in both countries (Proposition 3). Therefore, free trade (subject to a positive commodity tax imposed by Home) can be maintained in equilibrium if and only if the marginal disutility from pollution is sufficiently small. If, however, the marginal disutility from pollution is sufficiently large, then free trade (with or without commodity taxes) is not welfare improving as compared to autarky, so the two countries prefer Nash trade policies over Nash domestic policies, because they can still engage in trade and impose import tariffs, and improve their local welfare (Proposition 4).

\section{References}

[1] Antweiler, W., Copeland, B. R. \& Taylor, M. S. (2001). Is Free Trade Good for the Environment?. American Economic Review, 91(4), 877-908.

[2] Bang, J.K., Hoff, E. \& Peters, G.P. (2008). EU consumption, global production. World Wildlife Fund: Trade and Investment Programme.

[3] Barrett, S. (1994). Strategic environmental policy and international trade. Journal of Public Economics, 54, 826-39.

[4] Barrett, J., Peters, G., Wiedmann, T., Scott, K., Lenzen, M., Roelich, K., \& Le Quéré, C. (2013). Consumption-based GHG emission accounting: a UK case study. Climate Policy, 13(4), 451-70. 
[5] Brander, J. A., \& Krugman, P. R. (1983). A 'reciprocal dumping' model of international trade. Journal of International Economics, 15, 313-21.

[6] Brander, J. A., \& Spencer, B. J. (1984). Tariff protection and imperfect competition. In H. Kierzkowski (ed.), Monopolistic competition and international trade (194-206), Oxford: Oxford University Press.

[7] Brander, J. A., \& Spencer, B. J. (1985). Export subsidies and international market share rivalry. Journal of International Economics, 18, 83-100.

[8] Burquet R., \& Sempere, J. (2003). Trade liberalization, environmental policy, and welfare. Journal of Environmental Economics and Management, 46(1), 25-37.

[9] Copeland, B. R. \& Taylor, M. S. (1994). North-South trade and the environment. Quarterly Journal of Economics 109, 755-787.

[10] Copeland, B. R. \& Taylor, M. S. (1995). Trade and the Environment: A Partial Synthesis. American Journal of Agricultural Economics, 77(3), 765-71.

[11] Frankel, J. A., \& Rose, A. K. (2005). Is Trade Good or Bad for the EnvironmentSorting Out the Causality. Review of Economics and Statistics, 87(1), 85-91.

[12] Grossman, G.M. \& Krueger, A. (1993). Environmental impacts of a North American Free Trade Agreement. In P. Garber (ed.), The U.S.-Mexico Free Trade Agreement. Cambridge, MA: MIT Press.

[13] Holladay, S. (2008). Pollution from consumption and the trade and environment debate. University of Colorado Department of Economics Center for Economic Analysis Working Paper No. 2008/4.

[14] Koska, O.A. \& Stähler, F. (2016). The myth of profit-shifting trade policies. Economics Letters, 140(3), 39-41.

[15] Marques, A., Rodrigues, J. \& Domingos, T. (2013). International trade and the geographical separation between income and enabled carbon emissions. Ecological Economics, 89, 162-69.

[16] McCracken, S. \& Stähler, F. (2010). Economic integration and the choice of commodity tax base with endogenous market structures. International Tax and Public Finance, 17, 91-113.

[17] McCracken, S. (2015). The choice of commodity tax base in the presence of horizontal foreign direct investment. International Tax and Public Finance, 22, 811-833.

[18] Sato, M. (2013). Embodied Carbon in Trade: A Survey of the Empirical Literature. Journal of Economic Surveys, 1-31.

[19] Tanguay, G. A. (2001). Strategic environmental policies under international duopolistic competition. International Tax and Public Finance, 8, 793-811. 
[20] Ulph, A. (1996). Environmental Policy and International Trade When Governments and Producers Act Strategically. Journal of Environmental Economics and Management, 30(3), 265-81.

[21] Walz, U., \& Wellisch, D. (1997). Is free trade in the interest of exporting countries when there is ecological dumping? Journal of Public Economics, 66 (2), 275-91. 